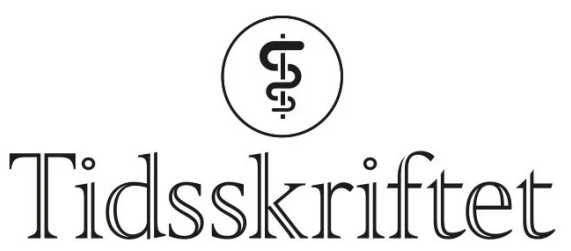

DEN NORSKE LEGEFORENING

\title{
Covid-19 med akutte magesmerter som debutsymptom
}

KORT KASUISTIKK

\section{HILDE BASTøE SELLEVOLL}

sbsehi@ous-hf.no

Avdeling for gastro- og barnekirurgi

Oslo universitetssykehus, Ullevål

Hilde Bastøe Sellevoll er lege i spesialisering i fødselshjelp og kvinnesykdommer.

Forfatteren har fylt ut ICMJE-skjemaet og oppgir ingen interessekonflikter.

\section{USMAN SAEED}

Seksjon for kolorektalkirurgi Avdeling for gastro- og barnekirurgi

Oslo universitetssykehus, Ullevål

Usman Saeed er spesialist i gastroenterologisk kirurgi og overlege.

Forfatteren har fylt ut ICMJE-skjemaet og oppgir ingen interessekonflikter.

\section{VICTORIA SOLVEIG YOUNG}

Seksjon for abdominal og onkologisk radiologi

Avdeling for radiologi

Oslo universitetssykehus, Ullevål/Aker

Victoria Solveig Young er spesialist i radiologi og overlege.

Forfatteren har fylt ut ICMJE-skjemaet og oppgir ingen interessekonflikter.

\section{GUNNAR SANDBAK}

Avdeling for radiologi

Oslo universitetssykehus, Ullevål/Aker

og

Det medisinske fakultet

Universitetet i Oslo

Gunnar Sandbæk er dr.med., MHA, spesialist i radiologi og overlege, avdelingsleder og førsteamanuensis.

Forfatteren har fylt ut ICMJE-skjemaet og oppgir ingen interessekonflikter.

\section{KARSTEN GUNDERSEN}

Avdeling for infeksjonssykdommer

Lovisenberg Diakonale Sykehus

Karsten Gundersen er lege i spesialisering i indremedisin.

Forfatteren har fylt ut ICMJE-skjemaet og oppgir ingen interessekonflikter. 


\section{En kvinne med akutte magesmerter ble innlagt med mistanke om kolecystitt. I tillegg til magesmerter hadde hun feberfølelse, oppkast, redusert matlyst og diaré. Hun hadde ingen luftveissymptomer, men viste seg likevel å ha covid-19. Tilsvarende er observert hos flere pasienter ved vårt sykehus. Dette har ført til midlertidig endrede rutiner i utredningen og håndteringen av pasienter med akutte magesmerter.}

En kvinne i slutten av 40-årene ble henvist til akuttmottaket ved regionssykehuset tidlig i koronaepidemien på grunn av akutte magesmerter og mistanke om kolecystitt. Pasienten hadde fra tidligere høyt blodtrykk, som var medikamentelt behandlet, og fedme med kroppsmasseindeks (BMI) $34 \mathrm{~kg} / \mathrm{m}^{2}$. Hun var mange år tidligere behandlet for miliærtuberkulose, med blant annet affeksjon av lunger og bukhinne. Hun hadde påvist gallestein ved en tidligere CT-undersøkelse, men hadde aldri hatt erkjente gallesteinsanfall.

Kvinnen rapporterte at hun hadde hatt konstante magesmerter i åtte dager før innleggelsen. Tidligere i uken hadde hun vært i kontakt med fastlegen, som hadde forskrevet esomeprazol (Nexium) 40 mg daglig grunnet mistanke om dyspepsi. Hun lokaliserte smertene til epigastriet og øvre høyre kvadrant, med symptomforverring etter matinntak. Pasienten rapporterte også om fluktuerende temperatur med daglig feberfølelse. I tillegg hadde hun redusert matlyst, kvalme, flere episoder med oppkast og en episode med diaré.

Ved klinisk undersøkelse var hun slapp og hadde redusert allmenntilstand. Kroppstemperaturen var $37,1^{\circ} \mathrm{C}$ etter at hun hadde tatt paracetamol. Respirasjonsfrekvensen var forhøyet, 28 per minutt, og oksygenmetningen ved pulsoksymetri var $95 \%$ ved romluft. Hun var takykard, med puls 100 slag per minutt. Det var normale funn ved auskultasjon av lungene. Ved undersøkelse av abdomen var det normale funn, foruten palpasjonsømhet under høyre kostalbue og i epigastriet. Hun hadde også smerter ved inspirasjon og palpasjon under høyre kostalbue (positivt Murphys tegn).

Blodprøvene viste forhøyet CRP $107 \mathrm{mg} / \mathrm{l}(\mathrm{o}-4)$, men normale leukocyttantall. Hun hadde normale lever- og galleprøver, men forhøyet laktatdehydrogenase $375 \mathrm{E} / \mathrm{l}$ (115-255).

Mottagende lege vurderte at kolecystitt var den mest sannsynlige årsaken til symptomene. Hun oppfylte ett av tre kriterier på qSOFA-skåringssystemet ( $\varnothing \mathrm{kt}$ respirasjonsfrekvens), og SIRS-skår var 2 av 4 ( $\varnothing \mathrm{kt}$ respirasjonsfrekvens og takykardi). Legen oppfattet kvinnen som infeksjonspreget og startet opp intravenøs antibiotikabehandling i form av piperacillin/tazobaktam $4 \mathrm{~g}$ tre ganger daglig.

Det ble rekvirert en ultralydundersøkelse av lever og galleveier, men ettersom pasienten var overvektig og flere radiologer var i karantene på grunn av den pågående koronaepidemien, valgte man å endre dette til en CT-undersøkelse med intravenøs kontrast. Ved CT av abdomen og bekken ble det ikke påvist aktuelle funn i buken, utenom gallestein som var kjent fra tidligere. Det var ingen radiologiske tegn på kolecystitt. På basale lungesnitt ble det imidlertid sett løst mettede fortetninger perifert i begge lunger samt enkelte områder med mer konsolidert preg. Det var ingen pleuravæske. Radiologen vurderte at funnene kunne passe med viral eller atypisk pneumoni (figur 1). 


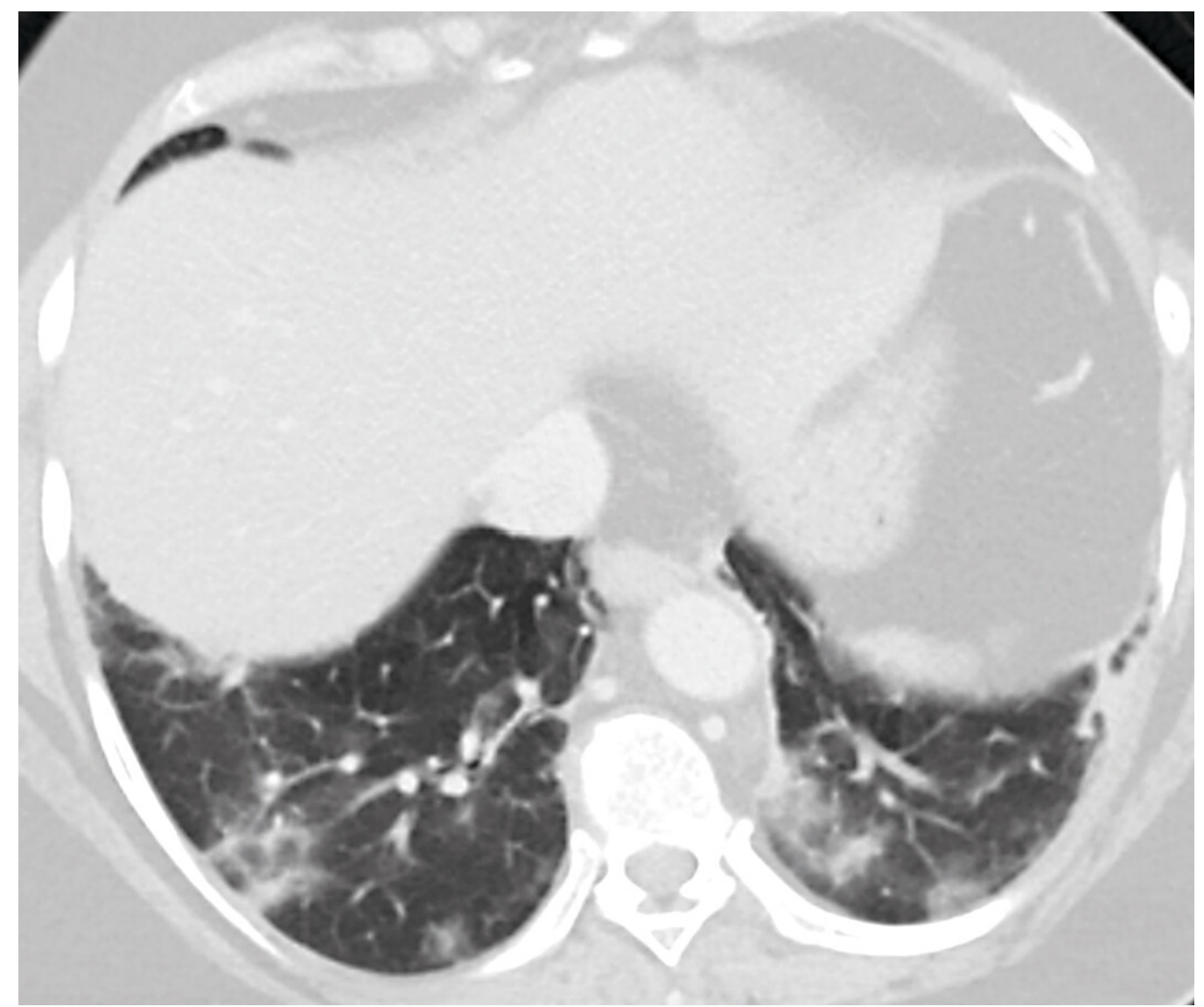

Figur 1 CT-bilde av basale lungesnitt som del av CT-undersøkelse av abdomen. Her vises perifere, flekkvise bilaterale mattglassfortetninger med innslag av konsolidering. Grunnet den pågående koronaepidemien ble det umiddelbart opprettet forsterket dråpesmitteisolering. Da kvinnen ble tilsett på nytt, hadde hun en temperatur på $38, \mathrm{o}^{\circ} \mathrm{C}$ og respirasjonsfrekvens på 20 per minutt. Oksygenmetningen var $94 \%$ på romluft. Ved ny utspørring anga pasienten at hun ikke hadde hoste, tungpustethet, vondt i halsen eller muskelsmerter. Hun benektet at hun hadde vært på reise de siste to ukene eller vært i nærkontakt med personer som hadde påvist covid-19. Likevel besluttet man å ta prøve fra nasofarynks og svelg for kvalitativ påvisning av sars-CoV-2-RNA med sanntids polymerasekjedereaksjon (PCR).

Virologisk undersøkelse bekreftet at pasienten var positiv for sars-CoV-2. Personell ved sykehuset som hadde vært i nærkontakt med pasienten før det ble opprettet dråpesmitteisolering, ble straks informert om 14 dagers karantene etter Folkehelseinstituttets retningslinjer (11). Pasienten ble overflyttet til infeksjonsmedisinsk avdeling ved sitt lokalsykehus. Hun utviklet ikke symptomer fra luftveiene i løpet av de neste to dagene og ble utskrevet i bedring, med plan om hjemmeisolasjon.

\section{Diskusjon}

11. mars 2020 erklærte Verdens helseorganisasjon det nye koronaviruset sars-CoV-2 som forårsaker covid-19 (2-4), for å være en global pandemi. Vanlige symptomer ved covid-19 er hoste, feber, muskelsmerter og slapphet med etter hvert utvikling av tungpustethet og akutt lungesviktsyndrom (acute respiratory distress syndrome, ARDS) hos enkelte (5-7.). Det typiske symptombildet med radiologiske funn av mattglassfortetninger og retikulære forandringer (crazy paving), har nylig vært beskrevet i en kasuistikk i Tidsskriftet (ㅁ).

Enkelte pasienter med covid-19 debuterer imidlertid med andre symptomer. I løpet av de siste to ukene har vi i vårt akuttmottak hatt ytterligere fem pasienter med tilsvarende symptombilde, der covid-19 har blitt bekreftet ved sanntids-PCR. Det dominerende symptombildet hos alle disse var magesmerter, der enkelte også hadde smerter i nedre del 
av buken. I tillegg rapporterte de om nedsatt matlyst, kvalme og oppkast. Noen hadde også diaré. Ingen hadde nytilkomne luftveissymptomer. Alle ble utredet med CT abdomen som ledd i utredningen av magesmerter, der bildene viste typiske funn for covid-19 i lungene (figur 2).

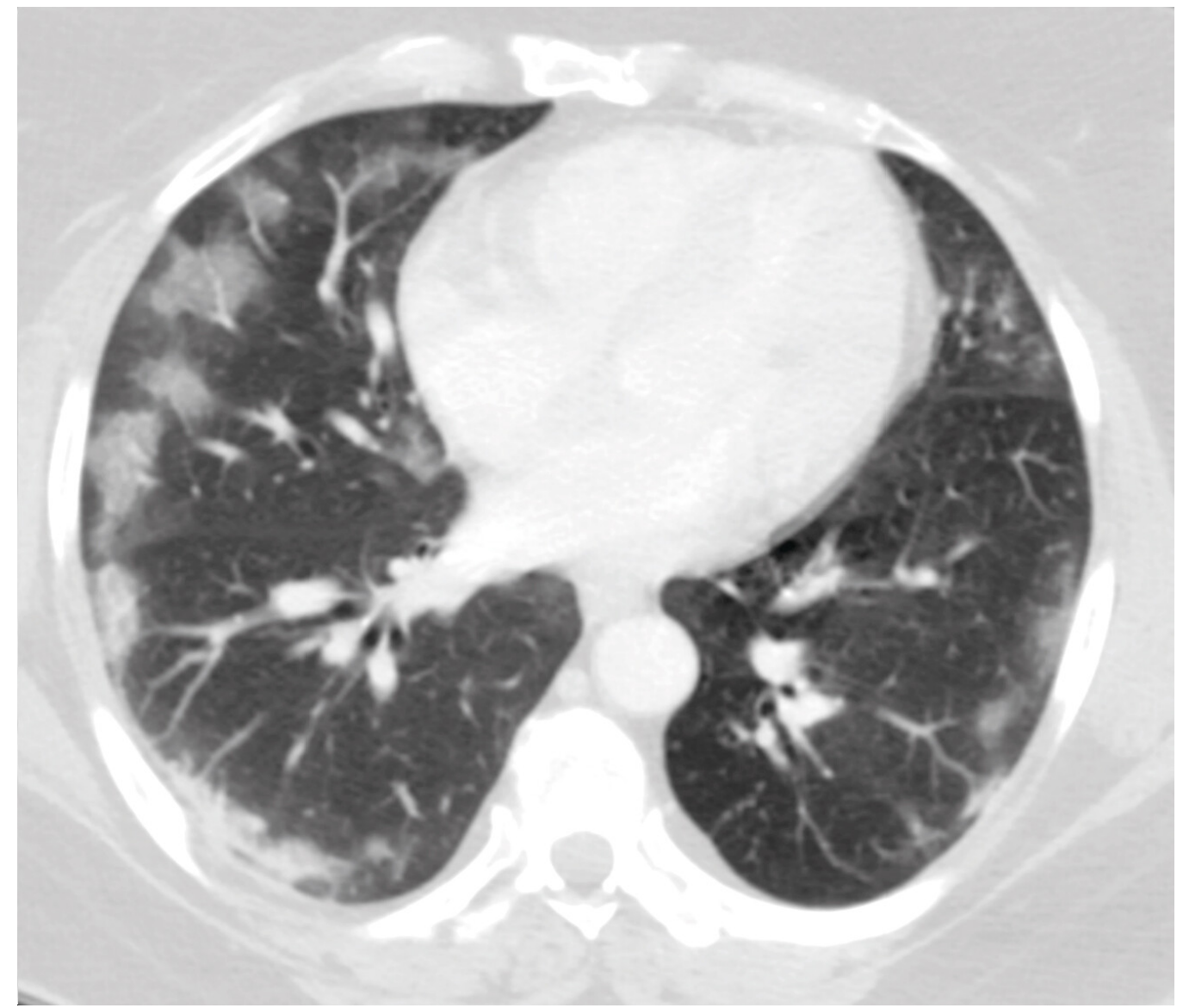

Figur 2 CT-bilde av pasient (ikke aktuelle kasuistikk) som hadde akutte magesmerter som debutsymtom. Bildet er fra nedre del av thorax og viser flekkvise, bilaterale karakteristiske mattglassfortetninger (melkeglassfortetninger) med perifer distribusjon. Pasienten har gitt samtykke til at bildet blir publisert.

I studier har man i $\emptyset$ kende grad rapportert om symptomer fra mage-tarm-kanalen ved covid-19-sykdom (ㅁ,7.7.9.). I en større studie med 1099 pasienter med covid-19 hadde $5 \%$ av pasientene kvalme og 3,8\% oppkast. I denne studien fant man også at $8,9 \%$ av pasientene aldri utviklet viral pneumoni (7.). I en helt nylig publisert studie av 204 pasienter med bekreftet covid-19 angis det at 48,5\% av pasientene hovedsakelig hadde symptomer med nedsatt matlyst, diaré, oppkast og magesmerter. Man fant at det var lengre tid fra symptomstart til innleggelse for pasienter med mage-tarm-symptomer enn for pasienter med luftveissymptomer, og at de med mage-tarm-symptomer hadde dårligere prognose (10 $)$.

Ved andre infeksjoner forårsaket av fylogenetisk lignende koronavirus, som Middle East Respiratory Syndrome (mers) og Severe Acute Respiratory Syndrome (sars), har man rapportert at $20-25 \%$ av pasientene initialt får symptomer fra mage-tarm-kanalen (11-13).

Basal pneumoni med pleuraaffeksjon kan forklare smerter og ubehag i øvre del av buken. Det er imidlertid mindre sannsynlig at basal pneumoni gir smerter i nedre del av buken og symptomer som kvalme, oppkast og diaré. Andre mekanismer må derfor mistenkes. På samme måte som sars-CoV har man vist at sars-CoV-2 har proteiner som binder seg lett til cellereseptoren angiotensinkonverterende enzym 2 (ACE2) (3). Det er mange ACE2reseptorer på type 2-alveolarceller i lungene, og lungene er derfor spesielt utsatt. Det er også vist at celler i andre organer har ACE2-reseptorer. Viruset kan derfor invadere, 
multiplisere seg og forårsake infeksjon i flere organsystemer. Man har sett en høy andel av ACE2-reseptorer i hjertet, ileum, spiserøret, nyrer og blære. I en studie ble det rapportert at epitelceller i ileum hadde svært høy andel ACE2-reseptorer (30\%, mot 1 \% i lungene) (14).

På bakgrunn av vår erfaring så langt med covid-19-pandemien har vi endret rutinene ved avdelingene for radiologi og for gastro- og barnekirurgi. Alle pasienter med uavklarte smerter i øvre del av buken og alle med magesmerter (uavhengig av lokalisasjon) med samtidig feber behandles som dråpesmittetilfeller inntil prøvesvar for covid-19 foreligger. Siden de typiske covid-19-funnene ikke nødvendigvis er lokalisert basalt i lungene, utføres nå også CT thorax samtidig med CT abdomen og bekken. Dette medfører ikke mye ekstra tidsbruk i CT-maskinen. Vi mener også at siden mange pasienter med akutte magesmerter ofte ender opp med en CT-undersøkelse i forløpet, bør man under denne epidemien vurdere primært å gjøre CT thorax, abdomen og bekken, i stedet for ultralydundersøkelse og konvensjonell røntgen thorax.

Tidlig mistanke om covid-19 er viktig for rask diagnostikk og for å redusere smitterisiko. Da vår pasient ble innlagt, var det allerede opprettet rutiner for tidlig vurdering av smitterisiko hos alle pasienter som kom til akuttmottak (pretriagering). I denne vurderingen inngår spørsmål om reiseanamnese og eventuell nærkontakt med personer med påvist covid-19. Det er lagt opp til «overtriage», og en stor andel av pasientene blir isolert med forsterket dråpesmitteregime. Pasienten vår gikk gjennom pretriagering etter gjeldende rutiner, men hun ble ikke smitteisolert.

Vår erfaring tilsier at uavklarte magesmerter bør inn som et kriterium i pretriagerutinene. Dette kan muligens redusere risiko for smittespredning til pasienter og ansatte i sykehus. Erfaringsgrunnlaget med covid-19 er imidlertid i en tidlig fase, og det må gjøres fortløpende vurderinger av de mest hensiktsmessige rutinene for pasienthåndtering.

Pasienten har gitt samtykke til at artikkelen blir publisert.

Artikkelen erfagfellevurdert.

\section{LITTERATUR}

1. Folkehelseinstituttet. Definisjon av nærkontakter til personer som har fått påvist covid-19. https://www.fhi.no/nettpub/coronavirus/helsepersonell/definisjoner-av-mistenkte-og-bekreftedetilfeller-med-koronavirus-coronavir/ Lest 25.3.2020.

2. Tan W, Zhao X, Ma X et al. A Novel Coronavirus Genome Identified in a Cluster of Pneumonia Cases - Wuhan, China 2019-2020. China CDC Weekly 2020; 2: 61-2. http://weekly.chinacdc.cn/en/article/id/a3907201-f64f-4154-a19e-4253b453d1oc Lest 30.3.2020.

3. Lu R, Zhao X, Li J et al. Genomic characterisation and epidemiology of 2019 novel coronavirus: implications for virus origins and receptor binding. Lancet 2020; 395: 565-74. [PubMed][CrossRef]

4. Verdens helseorganisasjon. WHO Director-General's opening remarks at the media briefing on COVID-19-11 March 2020. https://www.who.int/dg/speeches/detail/who-director-general-s-openingremarks-at-the-media-briefing-on-covid-19---11-march-2020 Lest 27-3.2020.

5. Huang C, Wang Y, Li X et al. Clinical features of patients infected with 2019 novel coronavirus in Wuhan, China. Lancet 2020; 395: 497-506. [PubMed][CrossRef]

6. Chen N, Zhou M, Dong X et al. Epidemiological and clinical characteristics of 99 cases of 2019 novel coronavirus pneumonia in Wuhan, China: a descriptive study. Lancet 2020;395: 507-13. [PubMed] [CrossRef]

7. Guan W, Ni Z, Hu Y et al. Clinical Characteristics of Coronavirus Disease 2019 in China. N Engl J Med 2020;382. doi: 10.1056/NEJMoa2002032. [PubMed][CrossRef]

8. Borén HK, Kjøstolfsen GH, Aaløkken TM et al. En mann i go-årene med feber og tørrhoste. Tidsskr Nor Legeforen 2020; 140. doi: 10.4045/tidsskr.20.0218. [CrossRef]

9. Wang D, Hu B, Hu C et al. Clinical Characteristics of 138 Hospitalized Patients With 2019 Novel Coronavirus-Infected Pneumonia in Wuhan, China. JAMA 2020;323: 1061. [PubMed][CrossRef]

10. Pan L, Mu M, Ren HG et al. Clinical characteristics of COVID-19 patients with digestive symptoms in Hubei, China: a descriptive, cross-sectional, multicenter study. Am J Gastroenterol 20.3.2020. 
https://journals.lww.com/ajg/Documents/COVID_Digestive_Symptoms_AJG_Preproof.pdf Lest 25.3.2020.

11. Assiri A, Al-Tawfiq JA, Al-Rabeeah AA et al. Epidemiological, demographic, and clinical characteristics of 47 cases of Middle East respiratory syndrome coronavirus disease from Saudi Arabia: a descriptive study. Lancet Infect Dis 2013; 13: 752-61. [PubMed][CrossRef]

12. Leung WK, To KF, Chan PKS et al. Enteric involvement of severe acute respiratory syndromeassociated coronavirus infection. Gastroenterology 2003; 125: 1011-7. [PubMed][CrossRef]

13. Zumla A, Hui DS, Perlman S. Middle East respiratory syndrome. Lancet 2015; 386: 995-1007. [PubMed][CrossRef]

14. Zou X, Chen K, Zou J et al. Single-cell RNA-seq data analysis on the receptor ACE2 expression reveals the potential risk of different human organs vulnerable to 2019-nCoV infection. Front Med 12.3.2020. https://link.springer.com/10.1007/s11684-020-0754-o Lest 23.3.2020.

Publisert: 31. mars 2020. Tidsskr Nor Legeforen. DOI: 10.4045/tidsskr.20.0262

Mottatt 25.3.2020, første revisjon innsendt 29.3.2020, godkjent 30.3.2020.

Publisert under åpen tilgang CC BY-ND. Lastet ned fra tidsskriftet.no 26. april 2023. 